\title{
Towards a Radical World Literature: Experimental Writing in a Globalizing World
}

Avant-garde and experimental writings have been associated with a wide range of political perspectives and agendas, including emancipatory struggles for social justice, "progressive" ideologies, militant actions, repressive regimes, and allegedly apolitical forms of creative expression. This special issue focuses on a radical strand of experimental world literature, one that participates critically and creatively in the ongoing struggle for affirmative social transformation in a globalizing world. This kind of radical literary experiment is indebted, at least in part, to the revolutionary ideas and practices of the nineteenth-century avant-garde, which inaugurated and inspired "a range of social postures and strategies for artists by which they could differentiate themselves from current social and cultural structures while also intervening in them" (Orton and Pollock 142). This spirit of avant-gardism ${ }^{1}$ continued to stimulate the emancipatory agendas and fictions of the twentieth century, including its anti-colonial, democratic, feminist/queer, and ecological movements. Such experiments have contributed to a radical imagination, understood as an ongoing and collective effort "to think critically, reflexively and innovatively about the social world" (Haiven and Khasnabish 2). However, in our contemporary era of neoliberal capitalism and stillincomplete decolonization, we suggest that radical experimental writing now faces distinctive creative challenges as it seeks to surpass the known limits of globalization's own world-making experiments and to inaugurate new forms of collective knowledge and coexistence.

This special issue investigates how contemporary experimental world literature mediates the scales, locations, and practices of globalization's world-making activities through its radical interventions. To frame the "problem" of experimental writing in a globalizing world, this introduction calls for a materialist world literary critique of writing that tests new propositions about social transformation and articulates alternatives to 
prevailing hegemonies and epistemologies. Specifically, we argue for the world-making potential of the textual experiment as it interrogates and rearticulates its position within the world literary field and the long history of social transformation. We reject the idea of an experimentalism that emanates from a single Western European centre or proceeds linearly and argue instead for a conjunctural approach to aesthetic and political resistance. If the twentieth century saw the waning of certain modes of experimentation, we also find ample evidence of the reawakening of experimental literatures in the contemporary period, especially in writing that seeks to renew and extend the call for social justice globally. We propose that the radical literary experiment interrogates its participation in the long history of globalization and renders visible other critical and creative views of transformation, particularly through its challenges to the inequalities that structure the prevailing global imaginary and world literary field. In the final part of this introduction, we discuss how the contributors to this collection address the radical experiment as a form of world-making that seeks to re-envision worldly belonging and coexistence on a planetary scale.

Our approach to experimental writing differs from that of The Oxford Dictionary of Literary Terms, which rather blandly defines literary experimentalism ${ }^{2}$ as " $[\mathrm{t}]$ he commitment to exploring new concepts and representations of the world through methods that go beyond the established conventions of literary tradition" (Baldick 120). This definition may suffice within communities that share a dominant construction of established literary conventions and a universalist conception of what constitutes "the world." But it does not account for the particularities of experimental world literatures that mediate the heterogeneous perspectives, cultural traditions, and political possibilities of an unevenly developed world-system. In our contemporary era of globalization, the literary experiment offers a fresh ethico-political articulation of the world as "an ongoing dynamic process of becoming, something that possesses a historical-temporal dimension and hence is continually being made and remade" (Cheah 42). In our view, experimental literatures not only participate in world-making but self-consciously foreground the challenges associated with their efforts to reconstitute globalization as 
a process of world historical transformation through the alternative accounts, knowledge, and critiques they seek to generate and disseminate.

This world literary perspective also differs from the largely formalist approach outlined by the editors of The Routledge Companion to Experimental Literature, who argue that " $\mathrm{t}]$ he one feature that all literary experiments share is their commitment to raising fundamental questions about the very nature and being of verbal art itself” (Bray, Gibbons, and McHale 1; emphasis in original). Interestingly, however, when the editors imagine the future of this mode of writing, they account for it in more worldly, political terms, suggesting that new forms of experimentation might arise in response to global crises. The editors observe that " $[\mathrm{t}]$ he present experimental literature ... of globalization ... seeks to challenge the forces of cultural and economic globalization, internationalism and capital markets" (17). They cite Occupy Wall Street, the Arab Spring, and protests against the Eurozone debt crisis as examples of political uprisings that might spark new forms of experimentation, predict that the global climate crisis "might spur the development of a politicized, experimental eco-literature" (18), and speculate that future forms of writing will be inspired by new media and digital technologies. Yet in doing so, they miss the fact that these radical forms of experimental writing and experimentalism have already emerged.

Experimentation in a globalizing world is not merely a belated response to world events, but shapes and is shaped by the histories, horizons, and various scales of globalization. As Suman Gupta observes, debates about globalization and literature are "meshed together so that they merge in a conjoined field that processes globalization in literature and the literariness of globalization" (69). Globalization is not just the subject of literature but also shapes the material field in which literary production, dissemination, and creative expression take place. Recent materialist analyses of the market conditions of world literature are crucial, particularly in their critique of the idealism associated with apolitical views of literature. ${ }^{3}$ We propose that global experimental texts betray a creatively anxious awareness of their own globalized status and its impact on their capacity to imagine the world differently. By opposing or problematizing conventional modes of writing, experimental writing 
interrogates its market status and capacity for creative autonomy and political agency in a globalizing world. Moreover, experimental writing self-consciously locates its aesthetic interventions within an unevenly constituted global literary marketplace for experimentation in which some literary conventions and knowledges prevail over others, such that aesthetic choices are necessarily politicized.

Creative writing today is contextualized by the experimental conditions of an incomplete process of world-making, one still as yet not fully known and therefore open to critical and creative propositions in order to discover and construct its realities. Through the exercise of its creative freedoms, the experimental text actively tests its participation in the struggle for global justice. It does so in two important ways. First, experimental writing in a globalizing world critiques and expresses alternatives to a world literary market structured by fundamental inequities, especially as they impact the dominant pedagogies, production, translation, distribution, and reception of creative writing. Second, in resisting the hegemonic culture that stabilizes the capitalist world order, experimental writing seeks alternatives to globalization while it confronts the challenges associated with its own imbrication within that world order. Consequently, experimental writing in a globalizing world maps and tests the limits of its own relationship to the world literary field as well as to prevailing imaginaries of the world, even as it seeks to awaken more ethical and participatory possibilities for globalization as a freshly reconstituted collective experiment in world-making.

\section{Radical Experimental Writing and Neoliberal Globalization}

Although we recognize the importance of circulatory and diffusionist constructions of world literature, this special issue focuses on literary experimentalism's historical articulations through time and space in conjuncture to struggles for justice. In his account of peripheral experimentation, George Yúdice argues that avant-gardism should be understood as "a transformative power that is generated whenever the conjunctural circumstances allow for it" (74). Renato Poggioli traces the "alliance of political and artistic radicalism" to avant-garde experiments in the nineteenth century, especially as embodied in the 1848 revolu- 
tions, noting their emergence with "the doctrine of art as an instrument for social action and reform, a means of revolutionary propaganda and agitation" (9). In the words of Gabriel-Désiré Laverdant, this kind of radical artistry initiates change through its efforts to "lay bare with a brutal brush all the brutalities ... which are at the base of our society" (qtd. in Poggioli 9). In the wake of the nineteenth-century avant-garde, twentieth-century writers continued to experiment both politically and aesthetically in order to articulate insurgent views, counter-hegemonic perspectives, and marginalized experiences. As Perry Anderson notes, a crucial coordinate of the modernist conjuncture in the 1920s and 1930s was the "imaginative proximity" of literary avant-gardes to the prospect of social revolution (104). Michael Denning similarly argues that what he calls "the novelists' international" of proletarian avant-garde literatures throughout the Global South co-emerged with anti-colonial and leftist movements (63).

A powerful antecedent for the contemporary radical imagination is the Paris Commune of 1871. In her invigorating account of the imaginary of "communal luxury" engendered by the Commune, Kristin Ross emphasizes the experiences of the men and women who brought it into being, showing how its working existence transformed the "common sense" of not only those involved but also that of subsequent generations of activists. She argues that the actions of the Communards transformed and expanded people's imaginations and thus enabled new ideas: "The Commune was, in this sense, a working laboratory of political inventions, improvised upon the spot or hobbled together out of past scenarios and phrases, reconfigured as need be, and fed by desires awakened in the popular reunions at the end of the Empire" (11). Ross' intervention is key to understanding not only the historical inventions of the Paris Commune but also the emergent imaginaries of contemporary radical social experiments, from the Occupy movement to the Zapatistas. This view decentres ideas of experimentation as originating in a single European centre and instead suggests that peripheral insurrections generate their own theories and practices of social transformation.

Consequently, even as we invoke the nineteenth-century avant-garde precedents of contemporary literary experimentation, we would like to 
complicate the notion of experimental writers as an intellectual "vanguard," emphasizing instead the degree to which new literary imaginaries emerge in proximity to new forms of praxis, which surface from radical social experiments and political movements. Drawing on his experience of radical social experiments in the twenty-first century that stress participatory approaches to collective global transformation, Boaventura de Sousa Santos makes a crucial distinction between "vanguardist theories," with their tendency to fetishize the inventions of privileged political elites, and what he calls "rearguard theories":

My work with the social movements has led me to ... prefer what I call rearguard theories, that is to say, the reflective work of facilitating rather than guiding, of walking with the social movements and taking care of those who walk more slowly, as Subcomandante Marcos would say, of bringing in scientific knowledge in order to build more robust constellations of knowledge (academic and non-academic knowledge) in the face of challenges posed in the concrete struggles. (Sousa Santos and Ziai 732)

This special issue suggests a need to map a fuller comparative history of radical world literary experimentation. It understands how contemporary writing might look to the future but also focuses on its rearguard theories, knowledge, and activity. Such an effort may complicate origin myths that locate the inception of the avant-garde in Paris in the nineteenth century, but we suggest that in so doing it remains true to the dissident spirit of communalism and internationalism, which advances a more sustainable and just future by attending to the claims of the disenfranchised, peripheralized, and dispossessed.

The field of new modernist studies has been preoccupied with global and planetary modernisms in recent years, unsettling accounts of modernism as expanding unidirectionally from a literary centre or as a product solely of the twentieth century. We do not advocate Susan Stanford Friedman's proposal of "multiple, polycentric, and recurrent modernities” (10), preferring instead Harry Harootunian's emphasis on “coeval ... modernities" in which "all societies shared a common reference pro- 
vided by global capital and its requirements" $(62,163)$. Nonetheless, we appreciate Friedman's efforts to map aesthetic moments of rupture in relation to the longue durée of socio-cultural transformations born of world-systemic shifts and her insistence on a planetary framework that entails multiple scales of spatio-temporal analysis (8-9). Modernism can be seen as entailing expansive and multi-scalar experiments in world-making, which remap and interrogate world historical moments of transition. Indeed, many of the experiments of nineteenth-century avant-garde, modernist, postmodernist, postcolonial, and post-millennial writing can be productively compared on the basis of their shared relationship to different historical stages of capitalist globalization. The dissident literatures emerging from emancipatory agendas throughout the twentieth and twenty-first centuries, including anti-colonial, anti-capitalist, feminist/queer, democratic, indigenous, and ecological movements, can be seen as part of a shared history of world-making experiments, always producing their imaginaries from out of the conditions of struggle.

Aesthetic experiments not only lend visibility to struggles against the injustices of capitalist development in a globalizing world but also disclose new cognitive maps and more ethical reckonings with the totality of global transformation. As Jacques Rancière argues, the politics of aesthetics are grounded in their capacity to reconfigure the perceptible (4). But the question remains how such reconfigurations might enact change in the world beyond the aesthetic moment and its potential impact on readers. In a globalizing world, literary experimentation mediates the particularities of heterogeneous perspectives, cultural traditions, and political possibilities unevenly situated throughout the world-system. Because of its capacity to exceed the limits of a dominant global imaginary, it can also initiate change in the world. In our view contemporary experimentation distinguishes itself through its efforts to rethink art's participatory role in world transformation.

Nonetheless, delinked from a radical emancipatory agenda, the experimental text can be co-opted for repressive political purposes or circulate as a commodity form evoking an illusory sense of emancipation. As Poggioli's study shows, avant-garde movements and poetics often 
gain "exchange currency" in the "international market of ideas," with the result that they may "no longer be used exclusively by those faithful to the revolutionary and subversive ideal" (12). Hence follows the petrification of styles, the retreat from radical politics, and the end of experimentation as a radical form of creative expression capable of worldmaking. In the global literary marketplace, experimental movements are all too vulnerable to co-option and appropriation, sometimes by the very hegemonies that they seek to dislodge. Experimental writing may wither away when it has been reduced to a mere set of recognizable styles and techniques, no longer intrinsically related to social transformation. Even the "experiment" in its scientific sense has been co-opted in an era that has seen the unprecedented corporatization of the sciences and the university and in which experimentation is no longer seen as a public good that produces knowledge as an end in itself but rather as an instrumentalist means through which to produce commodities for profit.

If the twentieth century witnessed an extension and elaboration of experimental writing through various social movements, particularly those of the 1960s, many twenty-first-century literary critics are concerned that the energies of these earlier radical aesthetic and political moments have been exhausted by neoliberal globalization, resulting in a waning of radical literary experimentation. Peter Bürger's Theory of the Avant-Garde underscores art's diminishing autonomy from political and economic spheres in the course of the twentieth century (50). In Twenty-First Century Fiction: What Happens Now, Jennifer Hodgson observes that " $\mathrm{t}$ ] oday, to speak of an experimental novel, much less the possibility of a literary avant-garde, seems rather like a quaint anachronism - a literary Sealed Knot of an old culture war" (30-31). She describes experimental writing as an "ailing art form" (32). Academic discourses concerning the post-postmodern turn (Nealon), the postcolonial eclipse (Loomba et al.), and debates about postfeminism (Faludi; McRobbie) variously address the fear that radical social thought and related emancipatory aesthetics had run their course by the end of the twentieth century.

In response to this problem of diminishing autonomy, we find useful John Roberts' suggestion that "autonomy-in-heteronomy provides a 
critique of autonomy itself (as a condition of art's resistance to its own aesthetic self-enclosure), and therefore provides a speculative place of engagement with non-art" (33; emphasis in original). Avant-garde and radical experiments engage in a "value struggle" between capitalism and other practices (Angelis 81), such that "even under advanced, global capitalism, outsides are continuously generated any time there is a struggle over the means of social reproduction or over the capacity for groups and collectives to engage in non-capitalist forms of exchange and relationality" (Mauro 123). By acting out its own value conflicts, the radical experiment lends new visibility to the wider fields of struggle that are common to the work of art and the world.

While certain historical forms of experimentation may have been depleted, we suggest that a new wave of contemporary experimentalism has emerged. Arguably, the very processes and conditions of ongoing globalization call for new forms of writing, whether as a quest for new forms of mimesis or a more radical and experimental effort to enact change. In her 2008 essay "Two Paths for the Novel," Zadie Smith proclaims that experimental writing is in decline, "relegated to a safe corner of literary history" and dismissed as a "fascinating failure." Yet her own fictional work continues to demonstrate an experimental realism that bridges overlapping styles to expose the brutalities of life in the unequal world of global capitalism. As such, Smith exemplifies both the crisis and renewal of experimental writing's political commitments. For some critics, the deaths of Roberto Bolaño and David Foster Wallace seemed to herald the end of the great experimental novel, but there is abundant evidence of experimentation in contemporary literary fiction (Skidelsky). The new millennium has witnessed a flourishing of avantgarde realism and experimental genre fiction driven by an interest in radical politics and poetics, expressed in the work of China Miéville, Yan Lianke, Junot Díaz, Xiaolu Guo, Hari Kunzru, César Aira, Andrea Levy, and Nalo Hopkinson, to name but a few. Within academia, there has also been a resurgent interest in experimentation in the last decade, evidenced in a wealth of studies and monographs. ${ }^{5}$

In light of the developmental cycles of capitalism, an approach to experimental writing that privileges a more cyclical sense of periodicity 
over linear periodization can help escape the impasse produced by critical debates over the exhaustion of aesthetics and that which might secede the "post-post." Rather than seeing literary experimentation as dead, exhausted, past, or superseded, it should be understood as occurring in multiple periods with intensities that wax and wane in conjuncture with socio-economic crises and political moments that demand new varieties of mimesis. Indeed, in a manifesto written with the Metaphysical Cinema Syndicate, Guo argues that contemporary artists confront the assimilation of previously avant-garde aesthetics into dominant culture, but that rather than despairing, they should seek instead to create "a life after death" in their innovation of new uncommodified forms of art to fit the present.

We suggest that a certain millennial sense of malaise has been countered by the emergence of new literatures that respond to globalized socio-political disruptions, including the events of $9 / 11$ and subsequent wars in Iraq and Afghanistan, the global economic crisis, the international social movements of Occupy and the Arab Spring, the civil war in Syria, climate change, and massive migrant upheaval. Peter Boxall argues that contemporary writing must not only grapple with "rapid transformations in the way that global time and space are produced, measured, and mapped" (7) but also find aesthetics in which to bear witness to "a growing disjunction between the material conditions of contemporary being, and those spatial and temporal forms in which such conditions become collectively meaningful" (9). ${ }^{6}$

Economic globalization is often periodized as a relatively recent phenomenon, typically associated with the "neoliberal turn" in economic policy, that encompasses the end of the Bretton Woods system, the dematerialization of money and the ascendancy of finance capital in the 1970s, the imposition of structural adjustment policies and debt across the former colonies of the Global South, and the transition to postFordism in capitalist cores. This period of modernity from the 1970s or early 1980s to the present has increasingly been referred to as an era of "neoliberalism," an umbrella term distinguishing a particular set of economic and political policies. Globalization has also been used as shorthand for the particular constellation of new technologies-includ- 
ing industrial outsourcing, the network and digital technologies of the information technology revolution, and the containerization and integration of transport networks - which have resulted in radical spacetime compression (Harvey) and the incorporation of the remainder of the world into a single market after the fall of the Berlin Wall in 1989. According to John Cavanaugh and Jerry Mander, globalization in the twentieth and twenty-first centuries has been shaped by deliberate forms of neoliberal "economic experiments" that have failed to deliver their stated promises of shared prosperity for the many and have concentrated instead on wealth creation for the few (xi).

Yet sociologists and world-systems theorists have argued for a longer historical view of globalization. We foreground the importance of reading globalization as a set of processes in relation to the longue durée of capitalism itself, with its expansive scales of spatio-temporal transformation across the five hundred years of capitalist modernity. Here, our thinking is shaped by the world-systems theory of Immanuel Wallerstein and Giovanni Arrighi and more particularly the critical debates that it has inspired, including Franco Moretti's "Conjectures on World Literature," Sharae Deckard, James Graham, and Michael Niblett's call for "world-literary criticism" of texts that take the world-system as their horizon of representation, and more recently the Warwick Research Collective's account of combined and uneven development. We use the idiosyncratic "globalizing world" in the title of this special issue to call attention to globalization not as a reified noun but as an ongoing process - a set of relations in motion whose history is still in the making and thus open to critical and creative intervention. This is a view that insists on the necessity of not treating globalization as an end in itselfas globalist celebrations of an end of history might do-but rather of imagining post-capitalist versions of a globalized world. At the same time, we recognize the residual and sometimes re-emergent influences of longer scales of development and transformation upon the contemporary globalizing world, and we suggest that a long historical view of social change should also extend to the history of creative expression.

In Globalization and Literature, Gupta criticizes efforts by critics such as Gilkes Gunn, Paul Jay, Stephen Greenblatt, and Rey Chow to expand 
the periodization of globalization beyond the contemporary; he argues that while Gunn et al. emphasize the need for historicist awareness in literary studies, they "mostly choose to empty the term 'globalization' of its historical and contextual content, to extend it retrospectively in an ahistorical and acontextual fashion" (10-11). We argue that precise historicization of world-systemic transformations over the longue durée can ameliorate this threat of over-extending the periodization of globalization, particularly as it comes to bear on world literary studies. We must reclaim the full history of globalization's losses and dispossessions in the course of the integration of the world under empire and global capitalism in order to construct a literary history of global transformation. If economic globalization has incorporated, homogenized, and eradicated alternative constructions and experiences of worldhood and planetary thinking, then literature plays an important role in rendering a sense of globalization's scope and scale as a world-historical process over the longue durée. An expansive, politically and ethically oriented understanding of globalization calls for rigorous and intensified efforts to think with and beyond world-systems analytics, recognizing the long, uneven, and sometimes unpredictable confluences that drive development and social transformation.

Sociologist Roland Robertson suggests that the contemporary era of globalization, from the 1970s onward, has been marked by an "intensification of consciousness of the world as a whole" and the pervasive sensation of the "compression of the world" (8). ${ }^{7}$ Arguably, the twentyfirst century is marked by an intensified consciousness of the planetary: as ecological crisis affecting the entirety of the biosphere and as global financial crisis marking a potentially epochal convulsion of capitalism itself. While commentators from Slavoj Žižek to Fredric Jameson argue that we confront this crisis with a paralysis born of our incapacity to imagine a world beyond capitalism, our current moment is nonetheless distinctive in the extent to which the apprehension of global crisis has become a shared structure of feeling. After 2008, class, capital, and inequality re-emerged as terms of critique in public discourse, and climate change is now indisputably posed as a global problem requiring both local and global transformations. The global horizon of the political has 
been revitalized, even if the forms new politics should take are not yet fully realized.

While all contemporary literature can be argued to be "world literary" in the sense that it is "literature of the world-system" (WReC 8), this special issue emphasizes world literature that negotiates this sense of politicized planetary consciousness. We are particularly interested in forms of experimental writing that mediate the challenges associated with the quest for alternatives to the hegemonic global order, beginning with the question of creative expression as an object and agent of social transformation. Given the proximity of political resistance and experimental aesthetics, perhaps the most fruitful way to approach the counter-poetics of this literature is in dialogue with critical debates and political movements against globalization, particularly in the form of alter-globalization, anti-capitalist, and global justice movements. The World Social Forum (WSF) coined the slogans "[a]nother world is possible" and "[a]nother world is needed" to express its aims of establishing alternatives to neoliberal globalization as represented by the World Economic Forum, the International Money Fund (IMF), and World Bank. Their mission statement describes the WSF as an "open meeting place for reflective thinking, democratic debate of ideas, formulation of proposals, free exchange of experiences and interlinking for effective action, by groups and movements of civil society that are opposed to neoliberalism and to domination of the world by capital and any form of imperialism" (“About"). Without setting out to align itself with the objectives of the WSF, this special issue is similarly motivated by a sense of the need for alternatives to hegemonic globalization-for revitalized forms of world literary research and criticism as well as of cultural production.

We suggest that global literary experimentation today confronts similar dilemmas as those who resist neoliberal globalization and seek alternatives to it. As Geoffrey Pleyers describes, the end of the twentieth century coincided with the devaluation of positivist and statist concepts of revolution, as many activists "woke up" from revolutionary dreams "only to realize that their emancipatory revolution had become an oppressive regime" (218). Yet this devaluation did not equal the end of all 
hopes of revolution; rather, it marked the emergence of new paradigms: "Alter-globalization activists believe that a pre-established plan does not and cannot exist, any more than a 'pre-fabricated model' can. ... Neither the participatory budget of Porto Alegre, nor the Zapatista experience represent models. ... Alter-globalization activists call upon a multiplicity of alternatives in order to create 'a world in which many worlds fit" (Pleyers 218). If capitalist globalization is an ongoing process, shaped in its current phase by neoliberal economic policies, alter-globalization represents one among several experimental political approaches to resisting and transforming capitalism's dominant logic. John C. Hawley argues that the global justice movement overlaps with the concerns of postcolonial scholars and world literary theorists in their shared commitments to a situated understanding of globalization from the vantage point of marginalized peoples and subjects (28-29). Alter-globalization movements conceive social transformation as a collective process, which necessitates widening participation across multiple scales, from the local to the transnational, while incorporating self-reflexive debate about global knowledge production, the forms collective action should take, and differences in subjective experience.

Similarly, the articles in this collection consider texts from around the world that contribute to the critique of hegemonic globalization, taking up Pheng Cheah's call for an ethico-political understanding of world literature "that does not merely describe and analyze how literary works circulate around the world or are produced with a global market in mind but that seeks to understand the normative force that literature can exert in the world" (5). We are interested in how literary experimentation inevitably transgresses the prevailing view of the globalized world, but also risks the possibility of failure each time it formulates and tests a proposition. Textual experiments may provide safe spaces for formulating new actions and knowledge in the world, whether through the instruction or warning they provide. But texts can also enact change in the world, acting upon readers to seed new forms of knowledge, interpretive practices, and frameworks for analysis. Experimental writing in a globalizing world succeeds to the extent that it reopens the world to further ethical inquiry and participatory action, revealing a space-time 
of possibility beyond the space-time compression of capitalist globalization. Just as writing cannot be severed from its worldly interactions and influences, so too must experimentation be seen as a self-reflexive and ongoing struggle to register, negotiate, and (re)construct the totality of worldly relations that encapsulate globalization.

\section{Overview of Essays}

This special issue brings together critical essays and an experimental literary manifesto to explore the ways in which experimental writing plays a role in revealing and resisting the inequalities associated with hegemonic development in a globalizing world. While some of the essays focus on globalization in the era of neoliberal economic experiments, others examine how the social experiments of postcolonial writing grapple with the legacies of imperialism and neo-imperialism imbricated in the longer history of globalization. The essays are united, however, by their emphasis on writers' self-reflexive awareness of the globalization of writing and readership in the contemporary era. They also share a concern with methodological innovation, calling for new forms of comparativism and integrated reading practices that acknowledge the distant proximities of globalized life, register the collective realities of the unequal world of global capitalism, and excavate the relations between various scales of socio-political movements. If globalization is in fact a worldmaking experiment, it is open to critical and creative interventions, especially through fictions that stake claims for art's capacity to participate in the inscription of this reorganization of planetary life. Nonetheless, the question of how to address and counter the seemingly total logic of globalization recurs as the crucial question of experimental writing in the contemporary era.

The opening essay by Diana Brydon addresses the troubled relationship of the postcolonial and the global in a world in which ongoing decolonization movements overlap with new calls for global justice. Her essay considers postcolonial literary experiments from Canada, Australia, and the Caribbean and reflects on how various textual experiments with scale and scalability disrupt dominant cognitive frameworks and prevailing epistemic borders. Brydon then considers how the fric- 
tion between different rationalities can spark new meaning and generate new spaces of visibility that exceed prevailing Western epistemes. She argues that contemporary postcolonial experiments challenge cognitive schemes of captivity and unshackle the global imaginary through decolonizing efforts to unleash alternative epistemologies and ecologies of knowledge.

Sharing Brydon's concern with scale and global justice, Sharae Deckard and Wendy Knepper each investigate how world literary experiments seek to imagine a world beyond global capitalist inequities through their cognitive mappings and articulations of new spaces of possibility. Moretti observes that world-systems analysis contributes to literary criticism by "allow[ing] us to 'see' a new literary genre-and not just any genre, but the one trying to represent the world as a totality: a possibility that our discipline had never even envisioned, because it lacked the concepts to do so" ("World-Systems Analysis" 67; emphasis in original). In this spirit, Deckard draws on world-systems and world-ecology approaches to read Rana Dasgupta's Solo as an example of world-mapping fiction. Her essay considers experimental writing in the context of structural narrative innovation and argues that Dasgupta welds together the realist forms of the historical novel and the Zeitroman in a diptych structure with a non-realist second half, a generic shift which attempts to negotiate the problem of imagining a world beyond capitalism. Also responding to Moretti and ideas of global epic, Knepper investigates how David Mitchell's Cloud Atlas experiments with globalized discourses, histories, and avant-garde practices of cannibalism to track and critique the violence associated with unfettered global capitalist accumulation in the longue durée. Such an epic reintegrates and mobilizes world cultural knowledge and global literacies to highlight the deprivations associated with uneven development, enact global cognitive justice, and involve readers as participants in articulating more ethical horizons for global transformation.

Drawing on world-systems analytic perspectives, Stephen Morton and Michael Niblett each reflect on how localized and subjective experiments can shed light on the global process of capitalist accumulation. Turning to the form of experimental poetry, Morton investigates the 
West Coast avant-garde poetics of the Kootenay School of Writing and the literary magazine Tish in relation to Vancouver's place in a global economic system subjected to neoliberal transformation. He argues that West Coast experimental writing is a form of peripheral modernism that both mediates and interrupts the uneven logic of capitalist development, inviting readers to reflect on the historical forms of dispossession associated with globalization and articulating an anti-imperialist poetics. Niblett's essay turns to the question of how literary style might mediate world-system and world-ecology in the period of late capitalism. Drawing on Theodor Adorno's reflections on late style, the essay provocatively compares the late work of Guyanese author Wilson Harris with English writer John Berger to explore the analogies between the writers' use of unconventional aesthetics to mediate the changes to human subjectivity and simplification of extra-human nature in the era of neoliberal financialization.

James Graham and Alison Gibbons highlight complexities that structure cosmopolitan formations and discourses. Graham's article considers the experimental mediation of uneven and combined development, turning to photographer David Goldblatt and writer Ivan Vladislavić's TJ/Double Negative, an experiment in inter-discursivity that brings together a photographic series with a metafictional novel. Graham argues that Goldblatt and Vladislavićs's collaborative, multi-modal work should be interpreted as experimental not only in form but in its generation of a critical cosmopolitanism situated in the historical colonial conditions and uneven capitalist development of modern Johannesburg. Gibbons analyzes how experiments in self-positioning disrupt homogenizing constructions of globalized subjectivity. Concentrating on linguistic experimentation, perceptual deixis, and relational narrative strategies, the article explores the pluralistic construction of the self in Brian Castro's fictional autobiography Shanghai Dancing.

Emphasizing the links between decolonization and global justice, Nicole Thiara and Paige Sweet consider the world literary dissemination of postcolonial perspectives. Thiara analyzes three contemporary Dalit novels whose complex narrative structures and fragmented poetics negotiate various scales of globalized experience, particularly in connec- 
tion with caste, national, and international audiences. She argues that authors' experimental use of oral narrative affirms the communal legacy of Dalit culture and projects a world free from caste discrimination. Translations of selected Dalit works echo this experimental approach as they seek to re-code the strangeness of these texts for international readerships. Sweet's analysis of Kgebetli Moele's Untitled: A Novel considers how the experimental representation of a (black) feminine subject position challenges gendered and sexual violence through a textual poetics that self-consciously negotiates literary forms as they circulate among multiple localities and positions within local and global frameworks of interpretation.

Elaborating on Judith Butler's recent work on war and detainment, Bianca Leggett and Golnar Nabizadeh focus on the biopolitical dimension of neoliberal globalization. Leggett examines Richard House's novel in four parts, The Kills, and explores how its fragmented form, multi-modality, and manipulation of the genre conventions of the thriller provide a counter-narrative to the reconstruction of Iraq and prompt readers to engage in a strategy of counter-reading. She conceptualizes the novel as a complex threnody that seeks to explode the "frames of war" (Butler) that mystify neo-imperialist intervention in Iraq and enable a more ethical reading of the role of United States' empire and transnational capital in processes of exploitation. Turning to the Australian context of migration and detention, Nabizadeh analyzes how an online graphic narrative, "At Work Inside Our Detention Centres: A Guard's Story," instantiates a multi-directional relationship between the guard, the reader, and the migrant and lends new visibility to the exceptions that structure Australian citizenship in world contexts.

Our two final contributions explore the role of experimental writing from the perspective of authorship and dissemination, reflecting on how neo-imperialism and the global literary marketplace exert pressure on creative freedoms. Harry Whitehead discusses the materialist conditions that structure the production and globalization of the American workshop model and argues that creative writing as a subject must better articulate its historical and cultural particularities. If not, it risks enacting a form of cultural imperialism in the production of future world 
literature, limiting the potential for radical literary experimentation. In particular, he considers the adoption of the workshop system in China, paying close attention to the perils associated with the homogenization of craft. Guo's experimental manifesto, "Words From a Brick in the Wall (Or, What the Dialectical Poet Tries to Say but Fails to Say, and What He Might Whistle or Sing)" provides a kindred warning and call for new forms of collective experimentation. The manifesto advocates for ongoing revolution in the face of uneven and combined development: "The only real revolution is a perpetual revolution. That's why it's impossible and unlivable for people. But it is possible in literature and in art" (Guo, Personal interview). She envisions a revolutionary art that moves through time like the arrow of Zeno's paradox, creating points of connection as it traverses and momentarily occupies various places: "There is no PLACE of perfect revolution since it's not a place. It's a process. It's not something we arrive at, but an imperative. It's an arrow. It always moves beyond itself" (Guo, Personal interview). Guo envisions experimental artistry as an active and ongoing exercise of the radical imaginary, one oriented toward the moving target of social justice.

Originally, Guo wrote the manifesto as an independent text, but she was unable to find a publisher for it, a fact that is not especially surprising in an era of publishing dominated by commercial imperatives. Nonetheless, writing the manifesto opened up new imaginative horizons for Guo, leading to her novel, I Am China. I Am China incorporates two globalized strands of revolutionary experimentalism: one that explores Western traditions of performance art and punk aesthetics and another that traces the exilic processes of migration and dissemination that emerge as a result of the violence associated with the June Fourth Incident of 1989 in Tiananmen Square. The manifesto gains a new resonance through its reappearance in I Am China as part of a lover's discourse. Through its experimental art and poetics of translation, the novel renews and repositions the manifesto as an experimental form in a globalized world: it becomes part of a wider field of social and textual experiments used to track the exclusions and exceptions that structure life within and beyond the nation. But the manifesto can also stand on its own, as it does here, as an exercise in dissident experimentation. 
Guo's manifesto invokes Chuang Tzu's famous tale of the man who dreams of being a butterfly, only to reawaken with a sense of uncertainty: " $[\mathrm{H}]$ ad I been Chuang Tzu dreaming I was a butterfly, or a butterfly dreaming I was now Chuang Tzu? However, there must be some sort of difference between Chuang Tzu and a butterfly! We call this the transformation of things" (Tzu 20). Through the experimental actions of the manifesto, Tzu's allegory gains new resonance in China's twentieth- and twenty-first-century world-making experiments in communism, insurrection, and global capitalism. The metaphysical questions Tzu poses surrounding the relationship between subject and world, dream and waking life, and imagination and actuality are re-historicized and politicized within the context of the manifesto. Guo thus envisions radical experiments in both Chinese and world literatures as a new space of collective possibility beyond the violence associated with hegemonic development and even avant-gardism's own militant actions.

We support Guo's suggestion that "[h]umans are experimental creatures; human life itself is an experiment; culture itself is an experiment. Art just reflects this general fact. Even mannerisms or dogmatic conventions are experiments, just experiments in conformity. So this will continue. The crucial question is what real experiments touch upon real unknown[s] and open up the space of possibility" (Guo, Personal interview). As Guo's remarks suggest, the human subject and the world are constituted through experiments in being and belonging, but the ends and means of those experiments require relentless scrutiny and inquiry. The experiment remains a risky proposition, a venture into the unknown. We suggest that contemporary forms of experimental writing in a globalizing world can lend creative insight into the histories, perils, and aspirations that underpin social experiments in world-making, and help reclaim repressed, marginalized, and eroded cultural forms and knowledges. In the process, experimental writing might well act as a guide for theorizing the world as a site of radically reconstituted collective knowledge and action.

Wendy Knepper and Sharae Deckard 


\section{Notes}

1 Cottington differentiates between the nominal and adjectival uses of the term "avant-garde": whereas the former (a concrete noun) refers to "a notional community of self-consciously aesthetically radical artists" (4), the latter alludes to certain qualities in a given work of art. He also observes that the attitude of avant-gardism emerged before the avant-garde as a radical group of committed artists came into being (4). This spirit of avant-gardism, including its challenges to the status quo, informs the experiments and qualities of experimentalism that interest us in this collection. In our view, avant-gardism forms part of an even more expansive radical world literature of experimentalism and experiments.

2 This special issue investigates experiments and experimentalism more generally. We distinguish between the terms "experimentation" and "experimentalism," suggesting that the former entails the performance of an experimental action while the latter describes a text that possesses experimental qualities. For instance, certain forms of realism or examples of genre fiction might not readily be categorized as experimental fictions. Nonetheless, they may exhibit an experimentalist attitude through an openness to the unknown, the quest for cognitive justice, alternative pathways for social transformation, and challenges to the status quo.

3 See Brouillette's powerful Bourdieusian critique of the commodification of postcolonial writers in the global literary marketplace and Casanova's investigation of power relations in what she calls "the world republic of letters."

4 Similarly, Sullivan suggests that "the problem with innovation in terms of the contemporary avant-garde, by and large, is that it has been co-opted by the market economy of late capitalism" (57). Badiou concludes: "More or less the whole of twentieth-century art has laid claim to an avant-garde function. Yet today the term is viewed as obsolete, even derogatory" (132).

5 See, for instance, Puchner's Poetry of the Revolution: Marx, Manifestos, and the Avant-Gardes, Winkiel's Modernism, Race and Manifestos, the New Literary History's special issue on the avant-garde in 2010 (Eburne and Felski), the Penguin Classics anthology entitled 100 Artists' Manifestos: From the Futurists to the Stuckists (Danchev), Sullivan's Experimental Writing in Composition: Aesthetics and Pedagogies, Grimstead's Experience and Experimental Writing: Literary Pragmatism from Emerson to the Jameses, Reed's Freedom Time: The Poetics and Politics of Black Experimental Writing, the emergence of the BAX (Best American Experimental Writing) annual anthology in 2014 (Swensen; Kearney), Contemporary Women's Writing's 2015 special issue on experimental writing (Mitchell), Lee's The Ethnic Avant-Garde: Minority Cultures and World Revolution, Roberts' aforementioned Revolutionary Time and the Avant-Garde, and Berry's Women's Experimental Writing: Negative Aesthetics and Feminist Critique.

6 Something of this spirit informs Bourriaud's claim that creative practitioners now find themselves in a position akin to modernists at the beginning of the 
twentieth century in their quest for new forms of mimesis: "[O]ur globalised perception calls for new types of representation: our daily lives are played out against a more enormous backdrop than ever before, and depend now on transnational entities, short or long-distance journeys in a chaotic and teeming universe." Yet Bourriaud's model of "altermodernism” problematically markets novelty and neologism for their own sake, reducing artistry to a belated response to globalization as its setting and context. This approach misses the constitutive role of cultural production in globalization as a process. Furthermore, his overdetermination of the singularity of the "altermodernist" moment overlooks the long historical emergence of capitalist modernity.

7 Arguably, this sensation is not wholly novel but rather a case of intensification in the wake of the integration of the world market; indeed, Jameson argues that the early twentieth-century modernist conjuncture was marked by an apprehension of intersubjectivity penetrated by larger external forces, so that the individual self could no longer be limned in purely local terms without reference to empire and capital's global expansion (Postmodern 411).

\section{Works Cited}

"About the World Social Forum." World Social Forum 2016. World Social Forum, 2016. Web. 13 Apr. 2016.

Aira, César. An Episode in the Life of a Landscape Painter. Trans. Chris Andrews. New York: New Directions, 2006. Print.

Anderson, Perry. "Modernity and Revolution." New Left Review I.144 (1984): 96113. Print.

Angelis, Massimo de. The Beginning of History: Value Struggles and Global Capital. London: Pluto, 2007. Print.

Arrighi, Giovanni. The Long Twentieth Century: Money, Power, and the Origins of Our Times. London: Verso, 1994. Print.

Badiou, Alain. The Century. Trans. Alberto Toscano. Cambridge: Polity, 2007. Print. Baldick, Chris. The Oxford Dictionary of Literary Terms. Oxford: Oxford UP, 2008. Print.

Berry, Ellen E. Women's Experimental Writing: Negative Aesthetics and Feminist Critique. London: Bloomsbury, 2016. Print.

Bourriaud, Nicolas. "Altermodern Explained: Manifesto." Tate Britain. Tate, 3 Feb. 2009. Web. 13 Apr. 2016.

Boxall, Peter. Twenty-First Century Fiction: A Critical Introduction. Cambridge: Cambridge UP, 2013. Print.

Bray, Joe, Alison Gibbons, and Brian McHale, eds. The Routledge Companion to Experimental Literature. London: Routledge, 2012. Print.

Brouillette, Sarah. Postcolonial Writers and the Global Literary Marketplace. Basingstoke: Palgrave, 2007. Print. 
Bürger, Peter. Theory of the Avant-Garde. Trans. Michael Shaw. U of Minnesota P, 1984. Print.

Casanova, Pascale. The World Republic of Letters. Trans. M. DeBevoise. Cambridge, MA: Harvard UP, 2004. Print.

Cavanagh, John, and Jerry Mander, eds. Alternatives to Economic Globalization: A Better World Is Possible. San Francisco: Berrett-Koehler, 2004. xi-xv. Print.

Cheah, Pheng. What Is a World? On Postcolonial Literature as World Literature. Durham: Duke UP, 2016. Print.

Cottington, David. The Avant-Garde: A Very Short Introduction. Oxford: Oxford UP, 2013. Print.

Danchev, Alex, ed. 100 Artists' Manifestos: From the Futurists to the Stuckists. London: Penguin, 2011. Print.

Deckard, Sharae, James Graham, and Michael Niblett. "Postcolonial Studies and World Literature.” Journal of Postcolonial Writing 48.5 (2012): 465-71. Print.

Denning, Michael. Culture in the Age of Three Worlds. London: Verso, 2004. Print.

Díaz, Junot. The Brief Wondrous Life of Oscar Wao. New York: Penguin, 2007. Print. Eburne, Jonathan P., and Rita Felski, eds. Introduction. What Is an Avant-Garde? Spec. issue of New Literary History 41.4 (2010): i-xvi, 695-934. Print.

Faludi, Susan. Backlash: The Undeclared War against Women. London: Vintage, 1993. Print.

Friedman, Susan Stanford. Planetary Modernisms: Provocations on Modernity across Time. New York: Columbia UP, 2015. Print.

Grimstead, Paul. Experience and Experimental Writing: Literary Pragmatism from Emerson to the Jameses. Oxford: Oxford UP, 2013. Print.

Guo, Xiaolu. Personal interview by Wendy Knepper. 22 Oct. 2015.

Guo, Xiaolu, Steve Barker, and Metaphysical Cinema Syndicate. "Notes towards a Metaphysical Cinema Manifesto.” guoxiaolu.com. Xiaolu Guo, 2010. Web. 20 Jan. 2016.

Guo, Xiaolu. A Concise Chinese-English Dictionary for Lovers. London: Vintage, 2007. Print.

—. I Am China. London: Vintage, 2014. Print.

Gupta, Suman. Globalization and Literature. Cambridge: Polity, 2008. Print.

Haiven, Max, and Alex Khasnabish. The Radical Imagination: Social Movement Research in the Age of Austerity. Halifax: Fernwood, 2014. Print.

Harootunian, Harry. History's Disquiet: Modernity, Cultural Practice, and the Question of Everyday Life. New York: Columbia UP, 2000. Print.

Harvey, David. A Brief History of Neoliberalism. Oxford: Oxford UP, 2005. Print.

- "Time-Space Compression and the Postmodern Condition." Literature and Globalization. Ed. Liam Connell and Nicky Marsh. London: Routledge, 2011. 5-17. Print.

Hawley, John C. "Agencies for Resistance, Prospects for Evolution.” The Postcolonial and the Global. Ed. Revathi Krishnaswamy and Hawley. Minneapolis: U of Minnesota P, 2008. 22-32. Print. 
Hodgson, Jennifer. "'Such a Thing as Avant-Garde Has Ceased to Exist': The Hidden Legacies of the British Avant-Garde Novel." Twenty-First Century Fiction: What Happens Now. Ed. Siân Adiseshiah and Rupert Hildyard. Houndmills: Palgrave, 2013. 15-33. Print.

Hopkinson, Nalo. The Salt Roads. New York: Warner, 2003. Print.

Jameson, Fredric. "Future City." New Left Review 21 (2003). Web. 20 Jan. 2016.

- Postmodernism, or, The Cultural Logic of Late Capitalism. London: Verso, 1991. Print.

Kearney, Douglas, ed. BAX 2015: Best American Experimental Writing. Middletown: Wesleyan UP, 2015. Print.

Kunzru, Hari. Transmission. London: Hamish Hamilton, 2004. Print.

Lee, Steven. The Ethnic Avant-Garde: Minority Cultures and World Revolution. New York: Columbia UP, 2015. Print.

Levy, Andrea. Small Island. London: Headline, 2004. Print.

Lianke, Yan. Lenin's Kissses. Trans. Carlos Rojas. London: Vintage, 2013. Print.

Loomba, Ania, Suvir Kaul, Matti Bunzl, Antoinette Burton, and Jed Esty, eds. Postcolonial Studies and Beyond. Durham: Duke UP, 2005. Print.

Mauro, Evan. "The Death and Life of the Avant-Garde: Or, Modernism and Biopolitics." Before and After Neoliberalism. Spec. issue of Mediations 26.1-2 (2012-13): 119-42. Print.

McRobbie, Angela. The Aftermath of Feminism: Gender, Culture and Social Change. London: Sage, 2009. Print.

Miéville, China. Perdido Street Station. New York: Ballantine, 2000. Print.

Mitchell, Kaye, ed. "Experimental Writing." Contemporary Women's Writing 9.1 (2015): 1-166. Print.

Moretti, Franco. "Conjectures on World Literature." New Left Review 1 (2000): 54-68. Print.

- "World-Systems Analysis, Evolutionary Theory, Weltliteratur." Immanuel Wallerstein and the Problem of the World: System, Scale, Culture. Ed. David Palumbo-Liu, Bruce Robbins, and Nirvana Tanoukhi. Durham: Duke UP, 2011. 67-77. Print.

Nealon, Jeffrey. Post-Postmodernism: Or, the Cultural Logic of Just-in-Time Capitalism. Stanford: Stanford UP, 2012. Print.

Orton, Fred, and Griselda Pollock. Avant-Gardes and Partisans Reviewed: Social History of Art. Manchester: Manchester UP, 1996. Print.

Pleyers, Geoffrey. Alter-Globalization: Becoming Actors in a Global Age. Cambridge: Polity, 2010. Print.

Poggioli, Renato. The Theory of the Avant-Garde. Cambridge: Belknap of Harvard UP, 1981. Print.

Puchner, Martin. Poetry of the Revolution: Marx, Manifestos, and the Avant-Gardes. Princeton: Princeton UP, 2005. Print.

Rancière, Jacques. The Politics of Literature. Trans. Julie Rose. Cambridge: Polity, 2014. Print. 
Reed, Anthony. Freedom Time: The Poetics and Politics of Black Experimental Writing. Baltimore: Johns Hopkins UP, 2014. Print.

Roberts, John. Revolutionary Time and the Avant-Garde. London: Verso, 2015. Print.

Robertson, Roland. Globalization: Social Theory and Global Culture. London: Thousand Oaks, 1992. Print.

Ross, Kristin. Communal Luxury: The Political Imaginary of the Paris Commune. London: Verso, 2015. Print.

Skidelsky, William. "Experimental Fiction: Is It Making a Comeback?" The Guardian. The Guardian, 1 Aug. 2010. Web. 13 Apr. 2016.

Smith, Zadie. "Two Paths for the Novel," New York Review of Books. New York Review of Books, 20 Nov. 2008. Web. 20 Jan. 2016.

Sousa Santos, Boaventura de, and Aram Ziai. "Reflections." Development and Change 44.3 (2013): 727-38. Print.

Swensen, Cole, ed. Best American Experimental Writing. Oakland: Omnidawn, 2014. Print.

Sullivan, Patricia Suzanne. Experimental Writing in Composition: Aesthetics and Pedagogies. Pittsburgh: U of Pittsburgh P, 2012. Print.

Tzu, Chuang. The Book of Chuang Tzu. Trans. Martin Palmer. London: Penguin, 2006. Print.

Wallerstein, Immanuel. "Structural Crisis in the World-System." Monthly Review 62.10 (2012). Web. 20 Jan. 2016.

Warwick Research Collective (WReC). Combined and Uneven Development: Towards a New Theory of World-Literature. Liverpool: Liverpool UP, 2015. Print.

Winkiel, Laura. Modernism, Race and Manifestos. Cambridge: Cambridge UP, 2008. Print.

Yúdice, George. "Rethinking the Theory of the Avant-Garde from the Periphery." Modernism and Its Margins: Reinscribing Cultural Modernity from Spain and Latin America. Ed. Anthony L. Geist and Jose Monleon. Minneapolis: U Minnesota P, 1999. 52-80. Print.

Žižek, Slavoj. Living in the End Times. London: Verso, 2011. Print. 